\title{
Early weaning PCB 95 exposure alters the neonatal endocrine system: thyroid adipokine dysfunction
}

\section{R G Ahmed}

Division of Anatomy and Embryology, Zoology Department, Faculty of Science, Beni-Suef University, Beni-Suef, PO 62514, Egypt

Correspondence should be addressed to R G Ahmed Email ahmedragab08@gmail.com or ragabb900@yahoo.com

\begin{abstract}
Polychlorinated biphenyls (PCBs) are persistent environmental pollutants that can severely disrupt the endocrine system. In the present study, early-weaned male rats were administered a single dose of 2,3,6-2', $5^{\prime}$-pentachlorinated biphenyl (PCB 95; $32 \mathrm{mg} / \mathrm{kg}$ per day, by i.p. injection) for two consecutive days (postnatal days (PNDs) 15 and 16) and killed 24 and $48 \mathrm{~h}$ after the administration of the last dose. Compared with the control group, administration of PCB 95 induced a reduction $(P<0.01)$ in serum concentrations of thyroxine, triiodothyronine, and $\mathrm{GH}$ and an increase $(P<0.01)$ in the serum concentration of TSH at PNDs 17 and 18 . These conspicuous perturbations led to some histopathological deterioration in the thyroid gland characterized by follicular degeneration, edema, fibrosis, hemorrhage, luminal obliteration, and hypertrophy with reduced colloidal contents at PND 18. The dyshormonogenesis and thyroid dysgenesis may be attributed to the elevation of DNA fragmentation at PNDs 17 and 18 . Furthermore, this hypothyroid state revealed higher $(P<0.01)$ serum concentrations of leptin, adiponectin, and tumor necrosis factor and lower $(P<0.01)$ serum concentrations of IGF1 and insulin at both PNDs compared with the control group. Interestingly, the body weight of the neonates in the PCB 95 group exhibited severe decreases throughout the experimental period in relation to that of the control group. These results imply that PCB 95 may act as a disruptor of the developmental hypothalamic-pituitary-thyroid axis. Hypothyroidism caused by PCB 95 may impair the adipokine axis, fat metabolism, and in general postnatal development.

Thus, further studies need to be carried out to understand this concept.
\end{abstract}

\author{
Key Words \\ - PCB 95 \\ - thyroid \\ - adipokines \\ - rat newborns
}

\section{Introduction}

Polychlorinated biphenyls (PCBs), a xenobiotic group of halogenated aromatic hydrocarbons, are the most hazardous, widespread, persistent, and ubiquitous environmental contaminants (Persky et al. 2012, Grimm et al. 2013, Murk et al. 2013). A large number of PCB congeners, about 209 PCBs, are produced and used in industrial materials and domestic products worldwide (Zoeller et al. 2002), and their toxicological properties depend on the number and position of chlorine substitutions (Leijs et al. 2012). In the United States, PCBs are manufactured as complex mixtures under the trade name Aroclor with a designation indicating the extent of chlorination (Karcher et al. 2004). The U.S. Environmental Protection Agency also recognizes PCBs as unavoidable toxins (2010 21CFR109.30.), because dairy products, meat, and fish are their sources (Persky et al. 2012, Grimm et al. 2013). 
These organohalogens are also bioaccumulated and biomagnified in the food chain and in the biological tissues to levels that are associated with a variety of health effects in human and animals (Miller et al. 2012). These potential effects are amplified and increased during development (Koibuchi \& Iwasaki 2006). Furthermore, in humans, they are mainly stored in the adipose tissue, with elimination half-lives of 6-10 years (Norstrom et al. 2010).

Importantly, the thyroid axis appears to be vulnerable to disruption by PCBs (Murk et al. 2013) and PCB metabolites (Sinjari \& Darnerud 1998), particularly during development, because most of these polyhalogenated hydrocarbons have the kinetics of highly lipid-soluble substances (Crofton et al. 2000b). Epidemiological studies have suggested that PCBs may affect growth and development by impairing thyroid function (Koopman-Esseboom et al. 1994, Kobayashi et al. 2009). However, their effects and precise toxicological mechanism(s) during development remain unclear. On the other hand, in animal and human studies, PCBs have been shown to disrupt adiponectin (Mullerova et al. 2008), leptin (Nieminen et al. 2000), tumor necrosis factor (TNF $\alpha$; Arsenescu etal. 2008), and insulin (Everett et al. 2011) concentrations, body weight, energy expenditure and fat depots (Anbalagan et al. 2003). However, studies on possible interactions between PCBs and adipokine concentration changes associated with thyroid dysfunction during the early weaning period are scarce.

As exposure to environmental contaminants is more likely to cause endocrine disturbances in neonates than in adults (Crofton 2004, Kobayashi et al. 2009), the aim of this study was to assess the effect of $2,3,6-2^{\prime}, 5^{\prime}$ pentachlorinated biphenyl (РСB 95), a toxic noncoplanar PCB congener (Schantz et al. 2003), on aspects of development of the thyroid axis and adipokine markers in albino rats at the early weaning period, particularly at postnatal days (PNDs) 17 and 18.

\section{Materials and methods}

\section{Animals and treatments}

The experimental animals used in this study were male white albino rats (24 pups aged 15 PND). The rats were obtained from the National Institute of Ophthalmology, Giza, Egypt. They were housed in cages and randomly divided into two groups: control and PCB 95. They were fed a standard rodent pellet diet manufactured by an Egyptian company producing oil and soap as well as some vegetables as a source of vitamins (Ahmed et al. 2010, El-bakry et al. 2010). Tap water was provided and the rats allowed to drink ad libitum. The rats were exposed to constant daily $12 \mathrm{~h}$ light: $12 \mathrm{~h}$ darkness each (lights on at $0600 \mathrm{~h}$ ) and $50 \pm 5 \%$ relative humidity (Ahmed \& Incerpi 2013). Generally, all the animal procedures were in accordance with the general guidelines of animal care and the recommendations of the Canadian Council on Animal Care (CCAC; Olfert et al. 1993). All efforts were made to minimize the number of animals used and their suffering.

The pups were given a single dose of PCB 95 (SigmaAldrich; $32 \mathrm{mg} / \mathrm{kg}$ per day, by i.p. injection) (Khan et al. 2002) for 2 consecutive days and killed 24 and $48 \mathrm{~h}$ after the administration of the last dose. At PNDs 17 and 18, the newborns were subsequently killed under mild diethyl ether anesthesia, and blood samples were collected and centrifuged at $1006.2 \mathrm{~g}$ for $30 \mathrm{~min}$. Clear, nonhemolyzed supernatant sera were removed quickly, divided into three portions for each rat, and kept at $-30{ }^{\circ} \mathrm{C}$ until use for different developmental and biochemical assays. The thyroid glands were removed and directly dissected on ice, washed with saline, patted dry on a filter paper, and weighed. The thyroid glands from three rats were pooled and homogenized in cold phosphate buffer (pH 7.4, $20 \mathrm{mM}$ ) (Mutaku et al. 1998) using a Teflon homogenizer (Glas-Col, Terre Haute, IN, USA). The thyroid homogenates were used for the DNA fragmentation assay. The thyroid glands of other rats were fixed in $10 \%$ neutral buffered formalin for study of the general histological structure (hematoxylin and eosin stain; Bancroft \& Stevens (1982)). Thyroid slides were examined under a light microscope for the presence of any histological changes. All reagents were of the purest grades commercially available.

\section{RIA examination}

The serum concentrations of thyroxine $\left(\mathrm{T}_{4}\right)$, triiodothyronine $\left(\mathrm{T}_{3}\right)$, thyrotrophin (TSH), growth hormone $(\mathrm{GH})$, and insulin-like growth factor 1 (IGF1) were estimated quantitatively by RIA at the Diabetic Endocrine Metabolic Pediatric Unit, Center for Social and Preventive Medicine, New Childrens Hospital, Faculty of Medicine, Cairo University, Egypt, according to the method of Thakur et al. (1997) for $\mathrm{T}_{4}$, Maes et al. (1997) for $\mathrm{T}_{3}$, Mandel et al. (1993) for TSH, Reutens (1995) for GH, and Dauncey et al. (1993) for IGF1. The kits were obtained from Calbiotech, Inc. (Spring Valley, CA, USA).

\section{Histological examination of the thyroid glands of neonates}

Some thyroid tissue samples, intended for histological examination by light microscopy, were immediately fixed

Published by Bioscientifica Ltd 
in $10 \%$ neutral buffered formalin and processed through a series of graded ethanol solutions. They were then embedded in paraffin, serially sectioned at $6 \mu \mathrm{m}$, and stained with hematoxylin-eosin at the National Cancer Institute, Cairo University, Egypt. The sections were cut parallel to the longitudinal axis of the trachea and were evaluated for the degree of thyroid injury.

\section{Biochemical examination of the thyroid glands of neonates}

The extent of DNA fragmentation was determined by the method adapted from that of Lin et al. (1997) and Shagirtha et al. (2011). Thyroid tissue homogenates were treated with $0.01 \mathrm{M}$ Tris buffer ( $\mathrm{pH} 8.0$ ), $1 \mathrm{mM}$ EDTA, and $0.5 \%$ Triton X-100 and centrifuged at $1006.2 \mathrm{~g}$ for $20 \mathrm{~min}$. Both the supernatant and pellet were precipitated with $12.5 \%$ TCA. Quantitative analysis of DNA was carried out by diphenylamine reaction. The percentage of fragmentation was calculated from the ratio of DNA in the supernatant to the total DNA.

\section{ELISA examination}

The serum concentrations of leptin, adiponectin, TNF $\alpha$, and insulin were determined by an immunoassay using a microplate reader (Spectra Max 190 - Molecular Devices, Sunnyvale, CA, USA) in my department laboratory. Commercial kits were used for the measurement of the concentrations of leptin, insulin, and adiponectin (ELISA kit - Millipore, St Charles, MO, USA). The TNF $\alpha$ ELISA kit was purchased from Invitrogen Corporation.

\section{Statistical analysis}

Data were analyzed using one-way ANOVA (PC-STAT, version 1A; University of Georgia, Athens, GA, USA) followed by least significant difference (LSD) analysis to determine the main effects and compare the groups with each other. F probability for each variable expresses the general effect between the groups. The data are presented as means \pm s.E.M., and values of $P<0.01$ and $P<0.001$ were considered statistically highly significant and very highly significant respectively.

\section{Results}

\section{Neonatal serum thyroid markers}

The concentrations of $\mathrm{T}_{4}, \mathrm{~T}_{3}, \mathrm{TSH}$, and $\mathrm{GH}$ in the control group increased gradually from PND 17 to PND 18 (Fig. 1).

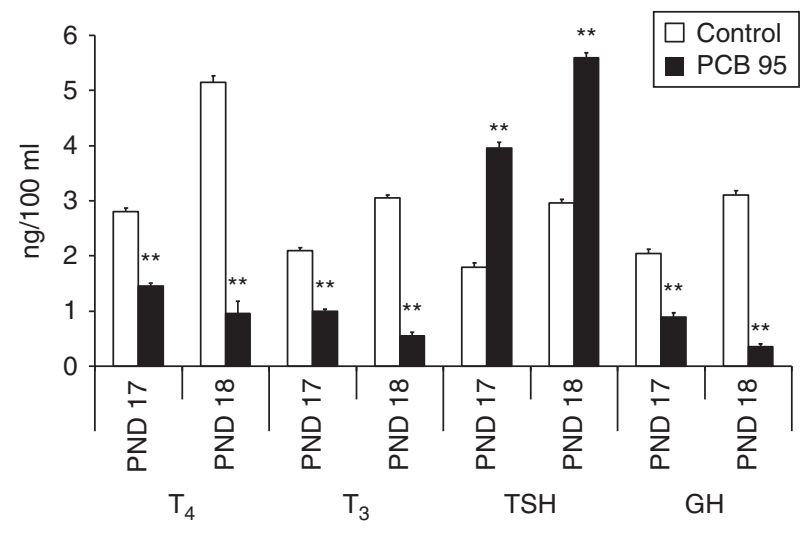

Figure 1

Serum concentrations of $\mathrm{T}_{4}, \mathrm{~T}_{3}, \mathrm{TSH}$, and $\mathrm{GH}$ (expressed in $\mathrm{ng} / 100 \mathrm{ml}$ ) of the control and $\mathrm{PCB}$ 95-treated newborns during the postnatal period. Bars represent means \pm s.E.M. of six rats/group, where the change between both the groups and PND is highly significant $(* * P<0.01)$ as determined by LSD analysis. ANOVA ( $F$ probability) indicates that the effect between the groups and tested PNDs is very highly significant $(P<0.001)$.

In the PCB 95-treated group, the concentrations of $\mathrm{T}_{4}$, $\mathrm{T}_{3}$ and $\mathrm{GH}$ were highly significantly $(P<0.01)$ lower at PND 17 when compared with the control group. This decrease was pronounced at PND 18, where the percentage indices for $\mathrm{T}_{4}, \mathrm{~T}_{3}$ and $\mathrm{GH}$ were $-81.55,-81.96$ and $-88.70 \%$ respectively. The reverse pattern was observed for the concentration of TSH, which was found to be higher $(P<0.01)$ in the PCB 95-treated group at PNDs 17 $(+119.44 \%)$ and $18(+89.18 \%)$ than in the control group. As one-way ANOVA was carried out for these hormones, the general effect between the groups and examined PNDs was found to be very highly significant $(P<0.001)$.

\section{Histological changes and DNA fragmentation in the thyroid glands of neonates}

The thyroid glands of the control pups exhibited normal distribution, morphology, and architecture of follicles and parafollicular cells at PND 18 (Fig. 2A). The lumina of these follicles varied from irregular rounded to tubular shape and had a single layer of cuboidal cells lining the epithelium. The administration of PCB 95 led to some subtle histopathological alterations in these follicles. The follicles were extremely damaged, and their lumina exhibited a severe degree of degeneration (Fig. 2B). Most of these follicles were enlarged with decreased colloidal contents in their lumina. There was also marked fibroblast proliferation between the follicles, hemorrhage, edema, and luminal obliteration at PND 18. Importantly, the follicles became very irregular and abnormal, also PCB 95 administration

Published by Bioscientifica Ltd. 

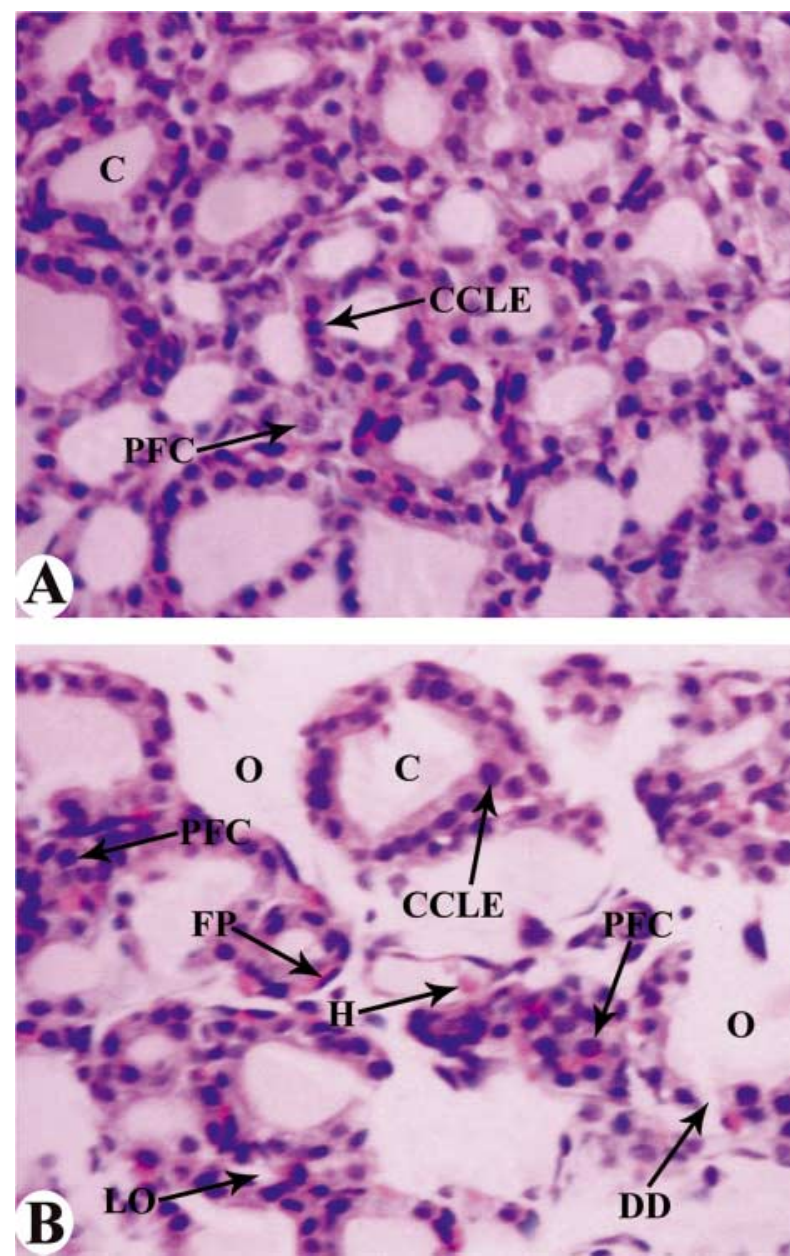

Figure 2

Representative HE-stained photomicrographs $(\times 400)$ of the thyroid glands of neonates at PND 18 (A: control group; B: PCB 95-treated group). $C$, colloid; CCLE, cuboidal cell lining epithelium; $D D$, destructive degeneration; FP, fibroblast proliferation; $\mathrm{H}$, hemorrhage; LO, luminal obliteration; O, edema; PFC, parafollicular cell. Full colour version of this figure available via http://dx.doi.org/10.1530/JOE-13-0302.

led to thyroid dysgenesis. On the other hand, the administration of PCB 95 increased the extent of DNA fragmentation from 8.42-fold at PND 17 to 9.55-fold at PND 18 when compared with the age-matched control group (Fig. 3). The general effect between the groups, on the DNA fragmentation at all the tested PNDs, was very highly significant $(P<0.001)$, as evaluated by one-way ANOVA.

\section{Neonatal serum adipokine markers, insulin, IGF1, and body weight}

In the control group newborns, the gradual increase in the concentrations of leptin, adiponectin, TNF $\alpha$, insulin, and IGF1 was associated with a profound increase in body weight from PND 17 to PND 18 (Figs 4 and 5). In the PCB 95-treated group, the concentrations of leptin, adiponectin, and TNF $\alpha$ were increased $(P<0.01)$ by 1.8-, 13.41-, and 9.3-fold respectively, while those of insulin and IGF1 were reduced $(P<0.01)$ by 0.4 - and 2 -fold respectively at PND 17 in comparison with the control group (Fig. 4). In addition, the concentrations of leptin, adiponectin, and TNF $\alpha$ were found to be increased by 2.95-, 22.3-, and 18.36-fold respectively, although the concentrations of insulin and IGF1 were found to be decreased by 1.42 - and 4.4-fold respectively in the PCB 95-treated group at PND 18 when compared with the control group (Fig. 4). Interestingly, the administration of $\mathrm{PCB} 95$ induced a maximal increase in the concentration of adiponectin at PND 18. Conversely, PCB 95 administration had a severe effect on the concentrations of insulin and IGF1, where their percentage index dropped from -50 and $-59.70 \%$ at PND 17 to -94.66 and $-87.12 \%$ at PND 18 respectively. On the other hand, the results indicate that the body weight of PCB 95-treated group newborns was lower $(P<0.01)$ than that of the control group newborns at PNDs 17 (-28.30\%) and 18 (-65.00\%) (Fig. 5). Based on one-way ANOVA of these parameters, it was found that the general effect between the groups was very highly significant $(P<0.001)$ throughout the experiment.

\section{Discussion}

The data presented herein clearly demonstrate the elevation in the serum concentrations of $\mathrm{T}_{4}, \mathrm{~T}_{3}, \mathrm{TSH}$, GH, and IGF1 in the control group at PNDs 17 and 18 . These observations are largely congruent with several

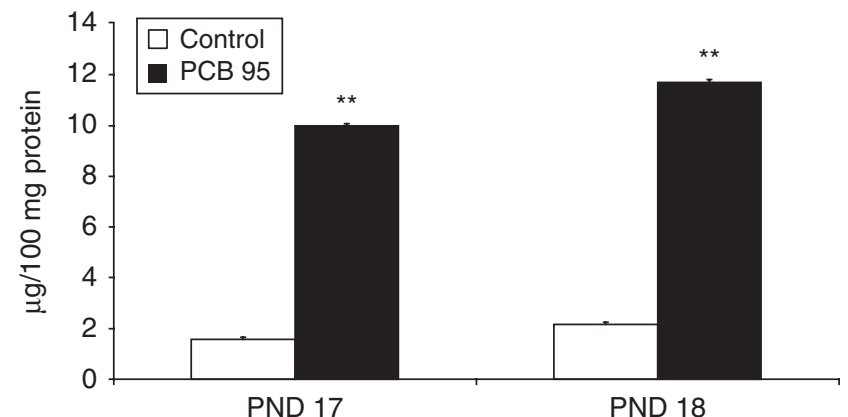

Figure 3

Level of DNA fragmentation (expressed in $\mu \mathrm{g} / 100 \mathrm{mg}$ protein) in the thyroid glands of the neonates in the control and PCB 95-treated groups during the postnatal period. Bars represent means \pm s.E.M. of six rats/group, where the change between both the groups/PND is highly significant $(* * P<0.01)$ as determined by LSD analysis. ANOVA ( $F$ probability) indicates that the effect between the groups and tested PNDs is very highly significant $(P<0.001)$.

Published by Bioscientifica Ltd. 


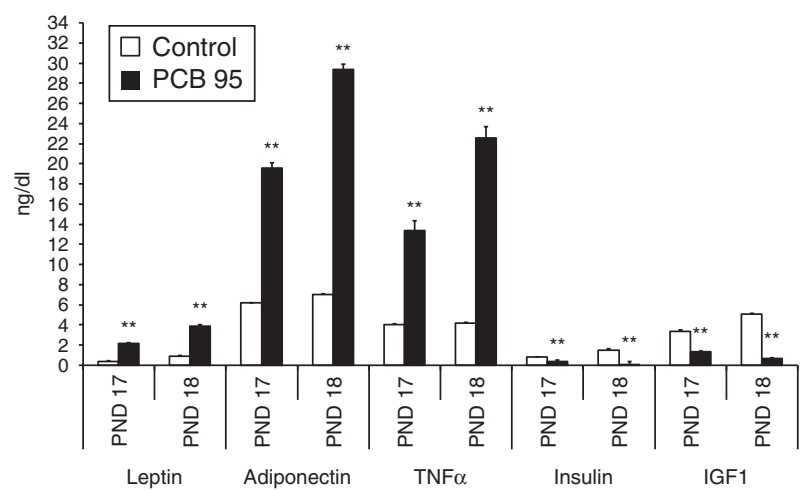

Figure 4

Serum concentrations of leptin, adiponectin, TNF $\alpha$, insulin, and IGF1 (expressed in $\mathrm{ng} / \mathrm{dl}$ ) of the control and PCB 95-treated newborns during the postnatal period. Bars represent means \pm s.E.M. of six rats/group, where the change between both the groups/PND is highly significant $(* * P<0.01)$ as determined by LSD analysis. ANOVA ( $F$ probability) indicates that the effect between the groups and tested PNDs is very highly significant $(P<0.001)$.

previously published results. The concentrations of thyroid hormones (THs; El-bakry et al. 2010, Saranac et al. 2013), TSH (Ahmed 2011, Ahmed et al. 2012a), and GH (Zimmermann 2011, Ahmed 2012) in neonates increase steadily until the thyroid gland is fully developed at the end of the fourth postnatal week (Ahmed et al. 2008). The serum concentration of IGF1 might also increase during the different growth periods (Kursunluoglu et al. 2009). These elevations may reflect the normal appearance of thyroid tissue and intact follicular structure as recorded in the present study. This in turn confirms that the gradual increase in the concentrations of TSH (Jahnke et al. 2004, Ahmed \& Incerpi 2013), GH (Ahmed 2011), and IGF1 (Kursunluoglu et al. 2009) is necessary for the development and growth of this gland.

In the present study, a significant increase in the serum concentrations of leptin, adiponectin, TNF $\alpha$, and insulin was observed in the control group at PNDs 17 and 18. Several publications support the view that adipokines might have an important role in fetal and postnatal development (Briana \& Malamitsi-Puchner 2010, Dündar et al. 2010, Marinoni et al. 2010, Savino et al. 2010, Ozard et al. 2012). Specifically, leptin, adiponectin, and TNF $\alpha$ are involved in the modulation of thyroid growth and function (Vázquez-Vela et al. 2008) and insulin sensitivity (Scherer 2006), and they may interact with TSH (Kato et al. 2006), GH (Fujimoto et al. 2005), and GH/IGF axis (Akin et al. 2009). An alternative explanation for the current findings is that the THs are important regulators of energy balance and intermediate metabolism, influencing serum adiponectin (Wang et al.
2008) and leptin (Ahmed \& Ahmed 2008) concentrations and glucose homeostasis (Fain \& Bahouth 1998). From the relationship between the previous observations and the present experiment, it can be inferred that the gradual increase in the concentrations of these markers is synergistic and closely interrelated with the behavior of the hypothalamic-pituitary-thyroid axis (HPTA) and GH/IGF1 axis during the postnatal period.

The elevation in the concentrations of thyroid and adipokine markers in the control group was accompanied by a marked increase in the body weight of neonates at both the examined PNDs. Concurrent with these results, positive relationships between the body weight of the neonates and the concentrations of THs (Ahmed et al. 2008, Wang et al. 2008), insulin and adiponectin (Tsai et al. 2004, Ng et al. 2005), leptin (Karastergioua \& Mohamed-Alia 2010), TNF $\alpha$ (Gao et al. 2008), and IGF1 (Zare et al. 2007) have been reported. Moreover, adiponectin, insulin, and leptin are key hormones that regulate fat mass storage, appetite, and energy homeostasis and could, therefore, be crucial components of postnatal adaptation (Hytinantti et al. 2008). This synergistic mechanism may be mediated by the thyroid axis and required for the development of fat metabolism.

In the present study, it was found that PCB 95 affected thyroid structure and function in the early weaning period. At PND 18, the administration of PCB 95 led to thyroid dysgenesis and the thyroid gland exhibited some histopathological changes, such as follicular destruction, luminal obliteration, edema, interfollicular fibroblast proliferation, hemorrhage, and hypertrophy with reduced colloidal contents. These histopathological alterations were associated with a tremendous decrease in the serum

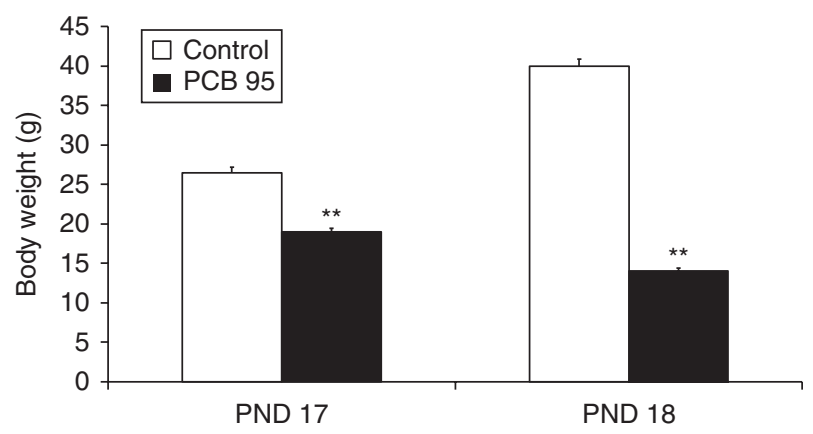

Figure 5

Changes in body weight (expressed in g) in the control and PCB 95-treated newborns during the postnatal period. Bars represent means \pm s.E.M. of six rats/group, where the change between both the groups/PND is highly significant $(* * P<0.01)$ as determined by LSD analysis. ANOVA ( $F$ probability) indicates that the effect between the groups and tested PNDs is very highly significant $(P<0.001)$.

Published by Bioscientifica Ltd. 
concentrations of $\mathrm{T}_{4}$ and $\mathrm{T}_{3}$ and a significant increase in the serum concentration of TSH at PNDs 17 and 18 when compared with the control group. PCB 95 administration also significantly increased DNA fragmentation in the thyroid glands of the neonates during the experimental period.

Similarly, treatment with PCBs leads to distinct histopathological changes in the thyroid gland (Tang et al. 2013), such as hyperplasia of the follicular epithelium, colloidal content reduction, vascularization, and lymphocyte infiltration in perifollicular areas $(\mathrm{Gu}$ et al. 2009). Furthermore, there is substantial evidence that perinatal exposure to PCBs and their hydroxylated metabolites decreases the concentrations of THs in the offspring (Crofton et al. 2000a,b, Meerts et al. 2002, Boas et al. 2012). Exposure to PCBs induces hypothyroidism (decreases the concentrations of THs and increases those of TSH) in rats (Khan et al. 2002, Powers et al. 2006), sledge dogs (Kirkegaard et al. 2011), monkeys (Boas et al. 2006), and children living near PCB-contaminated sites (Schell et al. 2004). Additionally, the elevation in DNA fragmentation reported herein is consistent with results of previous laboratory experiments showing that $\mathrm{PCBs}$ have the ability to break DNA strands (Ahlborg et al. 1992), where they may directly act on the thyroid receptor (TR) to modulate its action or indirectly act on an unknown TRbinding protein, which may then lead to conformational changes in the TR-DNA-binding domain to dissociate TR from the $\mathrm{T}_{3}$-responsive element (TRE; Miyazaki et al. 2008). Such lesions presumably contribute to altered thyroid function, leading to hypothyroidism (dyshormonogenesis). These explanations strengthen the possibility that the administration of PCB 95 may pose a significant risk for the pituitary-thyroid axis and this may lead to adverse developmental effects.

Collectively, results reported by many authors (Crofton \& Zoeller 2005, Miller et al. 2009, Patrick 2009, Grimm et al. 2013) indicate the following mechanisms to be involved in the impairment of thyroid function by PCBs: i) PCBs may reduce the ability of THs to bind to the transport proteins (transthyretin) in the bloodstream; ii) PCBs may impair the proteolysis of thyroglobulin; iii) PCBs may activate the aryl hydrocarbon receptors (AhRs), resulting in the elevation of the concentrations of several hepatic enzymes, including uridine diphosphate glucuronyl transferases and sulfotransferases; iv) PCBs may activate phase II conjugation of $\mathrm{T}_{4}$ (formation of $\mathrm{T}_{4}$-glucuronide $\left(\mathrm{T}_{4}-\mathrm{G}\right)$ ), resulting in the elevation of biliary excretion of $\mathrm{T}_{4}-\mathrm{G}$ and reduction in the circulating concentration of $\mathrm{T}_{4}$, leading to hypothyroidism; v) PCBs may inhibit or upregulate the production of deiodinases that allow $\mathrm{T}_{4}$ to be converted to $\mathrm{T}_{3}$; and vi) PCBs may act as either an agonist or an antagonist at the site of the cellular $\mathrm{TR}$, where they induce a partial dissociation of TR/retinoid $\mathrm{X}$ receptor (RXR) heterodimer complex from the TRE, resulting in the suppression of gene transcription. Although it is not clear which among these potential mechanisms are most important for mediating the effects of PCBs on the circulating concentrations of THs, it is likely that all are important to some extent in experimental models.

In the present study, a significant decrease in the serum concentrations of GH and IGF1 in the PCB 95hypothyroid group was observed at PNDs 17 and 18 in comparison with the control group. Several studies have found that prenatal exposure to PCBs leads to a decrease in the concentration of THs along with growth retardation in rat offspring (Bowers et al. 2004) and in infants (KoopmanEsseboom et al. 1994). This may be due to the loss of anabolism during hypothyroidism (Robson et al. 2002). Concurrently, hypothyroidism is associated with a significant decrease in the activities of IGF1 (Akin et al. 2009) and the GH/IGF1 axis (Ramos et al. 2001). Interestingly, the reduction in the concentration of GH can be attributed to the disruption of the activities of THs (Ahmed 2012), of the synthesis and release of growth hormone-releasing hormone (GH-RH), of the sensitivity of the pituitary gland to GH-RH, and of the transcription of the GH gene (Osfor et al. 2013). It has also been shown that the effects of THs on IGF1 synthesis and secretion are mediated by insulin in neonatal hypothyroid rats (Ramos et al. 2002). These findings are concomitant with those of the present study, where the depletion in the concentration of IGF1 was related to the alterations in the activities of THs and insulin that may delay growth. These findings imply that PCB 95 may disturb the GH/IGF1 axis during the postnatal period via the thyroid axis.

On the other hand, the serum concentrations of leptin, adiponectin, and TNF $\alpha$ were highly significantly increased even though the serum concentration of insulin was highly significantly decreased in the PCB 95-hypothyroid group at both the examined PNDs in comparison with the corresponding control group. In particular, the administration of PCB 95 at PND 18 led to a maximal increase in the concentration of adiponectin and the highest drop in the concentrations of insulin and IGF1, respectively. This is probably due to the disturbance of the hormonal homeostatic mechanisms on this day.

The results of the present study are in concordance with those of the study carried out by Chen et al. (2000)

Published by Bioscientifica Ltd. 
and Mazaki-Tovi et al. (2010), who demonstrated hyperleptinemia in the hypothyroid state. This state might be explained by the reduction in leptin turnover and degradation (Houseknecht et al. 1996) or stimulation of the HPTA in response to low TH concentrations in rats, dogs, and humans (Mazaki-Tovi et al. 2010). In contrast to these results, the serum concentration of leptin was found to be decreased during hypothyroidism (Ahmed et al. 2012b). Nieminen et al. (2000) also reported that subchronic exposure to PCBs has no effect on the plasma concentration of leptin. This discrepancy could be due to the experimental models, developmental period, and animal species used.

Moreover, in low TH concentration states, the serum concentration of adiponectin has been shown to increase significantly (Kokkinos et al. 2007), while the response of insulin to glucose has been shown to be delayed (Robson et al. 2002). The evidence reported by these authors is in agreement, to a large extent, with the results of the present study. In general, alterations in glucose and insulin metabolism due to PCBs and dioxins may be mediated by AhRs (Craft et al. 2002, Everett et al. 2011, Baker et al. 2013). In contrast to the findings of the present study, a negative correlation has been found between adiponectin concentration and PCB 153 (Mullerova et al. 2008), 3,3',4,4'-tetrachlorobiphenyl (PCB 77; Arsenescu et al. 2008), 2,3,7,8-tetrachlorodibenzo-p-dioxin (TCDD; Kern et al. 2004), and bisphenol A (BPA; Kidani et al. 2010). On the basis of these results, it is possible that the controversy about these markers may reflect the thyroid dysfunction due to PCB 95.

Furthermore, data reported herein support a positive association between serum TNF $\alpha$ concentration and weaning exposure to PCB 95. Previous studies have postulated that the exposure to coplanar РСВ 77 (a ligand of AhR) (Arsenescu et al. 2008, Baker et al. 2013), BPA (Ben-Jonathan et al. 2009), or a full mixture of PCB, organochlorine pesticides, and methylmercury (Hayley et al. 2011) promotes the production of proinflammatory adipokines, such as TNF $\alpha$ and interleukins (IL6 or IL12). The concomitant increase in the concentration of TNF $\alpha$ with a decreased activity of insulin, in the present study, may also be responsible for HPTA dysfunction. This might reflect the activation of AhR by PCBs (Crofton \& Zoeller 2005).

In the present study, it was found that the administration of PCB 95 resulted in a substantial decrease in the body weights of neonates at PNDs 17 and 18 when compared with those of members of the control group. These results are in agreement with a previous laboratory experiment showing that a lower dose of Aroclor 1254
(200 $\mu \mathrm{g} / \mathrm{kg}$ per day) (Anbalagan et al. 2003) or a higher dose of BPA (Nunez et al. 2001) induces a significant decrease in the body weight, fat depots, and feeding efficiency of rats. In immature rats and infants, low body weight during hypothyroidism is associated with reduced concentrations of serum GH, IGF, and carrier protein (Burstein et al. 1979). This could be attributed to the fact that THs (Ahima \& Flier 2000), leptin (Rosenbaum et al. 2005), and adiponectin (Qi et al. 2004) play a role in the reduction of body fat mass and body weight by stimulating energy expenditure and lipid oxidation. The loss of body weight may suggest a decline in the general health level of animals (Fernandes et al. 2007), which can be important in the interpretation of thyroid effects (Ahmed et al. 2008).

\section{Conclusion}

Five conclusions can be drawn from these data. The first is that the developmental exposure to РСВ 95 in the early weaning period seems to alter TH synthesis and secretion, either by acting directly on the thyroid gland or by acting on the pituitary or hypothalamic control of TSH or GH/IGF1 secretion. The second is that the administration appears to induce hypothyroidism via thyroid dysgenesis and dyshormonogenesis. These drastic effects may play a significant role in thyroid diseases. The third is that PCB 95 seems to play the role of a stress-responsive factor in the neonatal endocrine system (HPTA). The fourth is that hypothyroidism caused by РСВ 95 seems to alter the development of the adipokine axis, fat metabolism, and in general postnatal development. The final conclusion is that the administration of PCB 95 seems to lead to thyroid adipokine dysfunction (Fig. 6). These changes

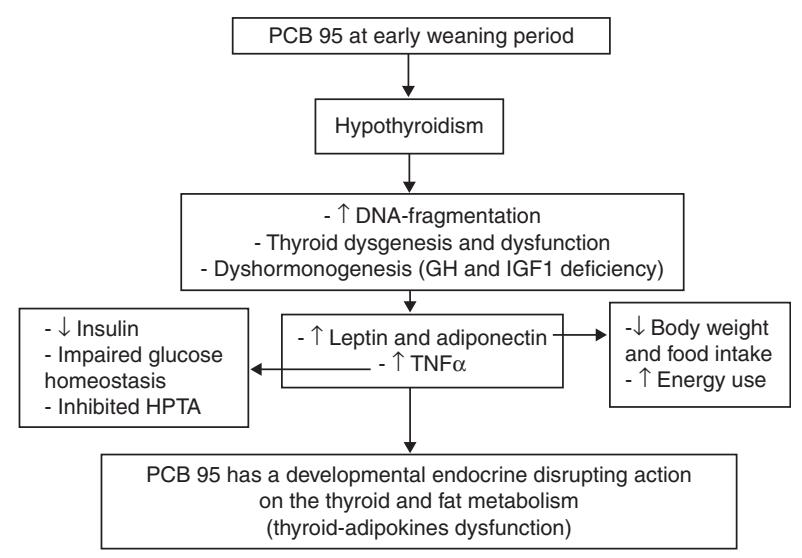

Figure 6

Schematic diagram of the toxic effect of early weaning PCB 95 exposure on the developmental endocrine adipokine homeostasis.

Published by Bioscientifica Ltd. 
may be either directly or indirectly related to TH action. More interestingly, the toxicity of PCBs is dependent on compound congeners, dose, exposure duration, developmental period, and the species involved. From this, it can be concluded that the endocrine-disrupting compounds can exert complex, mosaic effects during an animal's life cycle (Zoeller et al. 2012). Further investigations are required to elucidate the potential associations with human health.

\section{Future direction}

- Studies focusing on the direct relationship between HPTA and fat tissue are needed to clarify the developmental interactions between thyroid function status and adipokines. Future research should also determine the dose of PCBs received by developing rats from placental and lactation exposure, as well as the hepatic catabolic responses of developing neonates to PCBs, to explain the lack of effects of PCBs at later postnatal ages.

- Longitudinal studies of the developmental neuroendocrine system in newborns/infants should be carried out in fish-eating populations because fish is a major source of PCBs. Any degree of thyroid disruption that affects the concentrations of THs on a population basis should be considered a biomarker of adverse outcomes, which may have important societal effects (Miller et al. 2009).

- Future studies also need to elucidate important interactions among contaminants, hormones, protein expression, and other phenotypic or physiological measures to gain understanding of what factors - or groups of factors - are driving phenotypic changes in animals living in affected environments.

\section{Declaration of interest}

The author declares that there is no conflict of interest that could be perceived as prejudicing the impartiality of the research reported.

\section{Funding}

This work was supported by a National Grant from the Research Center, Beni-Suef University, Beni-Suef, Egypt.

\section{Acknowledgements}

The author is grateful to all staff in his department for technical assistance. The author also cordially thanks Prof. Dr Paul J Davis (Department of Medicine, Albany Medical College, USA), Prof. Dr Sandra Incerpi (Department of Sciences, University of Rome 'Roma Tre', Italy), and
Prof. Dr Kevin M Crofton (Integrated Systems Toxicology Division, MD-B105-04, National Health and Environmental Effects Research Laboratory, U.S. Environmental Protection Agency, North Carolina, USA) for their assistance.

\section{References}

Ahima RS \& Flier JS 2000 Adipose tissue as an endocrine organ. Trends in Endocrinology and Metabolism 11 327-332. (doi:10.1016/S10432760(00)00301-5)

Ahlborg UG, Hanberg A \& Kenne K 1992 Risk assessment of polychlorinated biphenyls (PCBs). In Report Nord 26, p177. Eds UG Ahlborg, Å Bergman, H Håkansson, B Jansson, S Skerfving, S Slorach, J Alexander, E Dybing, JU Skåre, J Rantanen, Eyrjänheikki, AA Jensen, P Grandjean \& JC Larsen. Copenhagen, Denmark: Nordic Council of Ministers.

Ahmed RG 2011 Perinatal 2,3,7,8-tetrachlorodibenzo-p-dioxin exposure alters developmental neuroendocrine system. Food and Chemical Toxicology 49 1276-1284. (doi:10.1016/j.fct.2011.03.008)

Ahmed RG 2012 Maternal-newborn thyroid dysfunction. In Developmental Neuroendocrinology pp 1-369. Ed RG Ahmed. LAP LAMBERT Academic Publishing GmbH \& Co KG: Saarbrücken, Germany.

Ahmed RR \& Ahmed OM 2008 Probable thermogenic mechanisms during hyperthermia in developing albino rats: physiological histological and immunohistochemical studies. Journal of Egyptian German Society of Zoology 56A 87-120.

Ahmed RG \& Incerpi S 2013 Gestational doxorubicin alters fetal thyroidbrain axis. International Journal of Developmental Neuroscience 31 96-104. (doi:10.1016/j.ijdevneu.2012.11.005)

Ahmed OM, El-Gareib AW, El-bakry AM, Abd El-Tawab SM \& Ahmed RG 2008 Thyroid hormones states and brain development interactions review. International Journal of Developmental Neuroscience 26 147-209. (doi:10.1016/j.ijdevneu.2007.09.011)

Ahmed OM, Abd El-Tawab SM \& Ahmed RG 2010 Effects of experimentally induced maternal hypothyroidism and hyperthyroidism on the development of rat offspring: I. The development of the thyroid hormones-neurotransmitters and adenosinergic system interactions. International Journal of Developmental Neuroscience 28 437-454. (doi:10.1016/j.ijdevneu.2010.06.007)

Ahmed OM, Ahmed RG, El-Gareib AW, El-Bakry AM \& Abd El-Tawab SM $2012 a$ Effects of experimentally induced maternal hypothyroidism and hyperthyroidism on the development of rat offspring: II. The developmental pattern of neurons in relation to oxidative stress and antioxidant defense system. International Journal of Developmental Neuroscience 30 517-537. (doi:10.1016/j.ijdevneu.2012.04.005)

Ahmed OM, Abdel Gabar M \& Ali TM 2012 $b$ Impacts of the coexistence of diabetes and hypothyroidism on body weight gain leptin and various metabolic aspects in albino rats. Journal of Diabetes and its Complications 26 491-500. (doi:10.1016/j.jdiacomp.2012.05.021)

Akin F, Yaylali GF, Turgut S \& Kaptanoglu B 2009 Growth hormone/ insulin-like growth factor axis in patients with subclinical thyroid dysfunction. Growth Hormone \& IGF Research 19 252-255. (doi:10.1016/ j.ghir.2008.11.003)

Anbalagan J, Kanagaraj P, Srinivasan N, Aruldhas MM \& Arunakaran J 2003 Effect of polychlorinated biphenyl Aroclor 1254 on rat epididymis. Indian Journal of Medical Research 118 236-242.

Arsenescu V, Arsenescu RI, King V, Swanson H \& Cassis LA 2008 Polychlorinated biphenyl-77 induces adipocyte differentiation and proinflammatory adipokines and promotes obesity and atherosclerosis. Environmental Health Perspectives 116 761-768. (doi:10.1289/ ehp.10554)

Baker NA, Karounos M, English V, Fang J, Wei Y, Stromberg A, Sunkara M, Morris AJ, Swanson HI \& Cassis LA 2013 Coplanar polychlorinated biphenyls impair glucose homeostasis in lean C57BL/6 mice and mitigate beneficial effects of weight loss on glucose homeostasis in 
obese mice. Environmental Health Perspectives 121 105-110. (doi:10.1289/ehp.1205421)

Bancroft JD \& Stevens A 1982 In Theory and practice of histological techniques, pp 121. 2nd Edn. Edinburgh, UK: Churchill-Livingstone.

Ben-Jonathan N, Hugo ER \& Brandebourg TD 2009 Effects of bisphenol A on adipokine release from human adipose tissue: implications for the metabolic syndrome. Molecular and Cellular Endocrinology 304 49-54. (doi:10.1016/j.mce.2009.02.022)

Boas M, Feldt-Rasmussen U, Skakkebæk NE \& Main KM 2006 Environmental chemicals and thyroid function - invited review. European Journal of Endocrinology 154 599-611. (doi:10.1530/eje.1.02128)

Boas M, Feldt-Rasmussen U \& Main KM 2012 Thyroid effects of endocrine disrupting chemicals - review. Molecular and Cellular Endocrinology 355 240-248. (doi:10.1016/j.mce.2011.09.005)

Bowers WJ, Nakai JS, Chu I, Wade MG, Moir D, Yagminas A, Gill S, Pulido O \& Meuller R 2004 Early developmental neurotoxicity of a PCB/ organochlorine mixture in rodents after gestational and lactational exposure. Toxicological Sciences 77 51-62. (doi:10.1093/toxsci/kfg248)

Briana DD \& Malamitsi-Puchner A 2010 The role of adipocytokines in fetal growth. Annals of the New York Academy of Sciences 1205 82-87. (doi:10.1111/j.1749-6632.2010.05650.x)

Burstein PJ, Draznin B, Johnson CJ \& Schalch DS 1979 The effect of hypothyroidism on growth, serum growth hormone, the growth hormone-dependent somatomedin, insulin-like growth factor, and its carrier protein in rats. Endocrinology 104 1107-1111. (doi:10.1210/ endo-104-4-1107)

Chen MD, Song YM, Tsou CT, Lin WH \& Sheu WH 2000 Leptin concentration and the $\mathrm{Zn} / \mathrm{Cu}$ ratio in plasma in women with thyroid disorder. Biological Trace Element Research 75 99-105. (doi:10.1385/ BTER:75:1-3:99)

Craft ES, DeVito MJ \& Crofton KM 2002 Comparative responsiveness of hypothyroxinemia and hepatic enzyme induction in Long-Evans rats versus C57BL/6J mice exposed to TCDD-like and phenobarbital-like polychlorinated biphenyl congeners. Toxicological Sciences 68 372-380. (doi:10.1093/toxsci/68.2.372)

Crofton KM 2004 Developmental disruption of thyroid hormone: correlations with hearing dysfunction in rats. Risk Analysis 24 1665-1671. (doi:10.1111/j.0272-4332.2004.00557.x)

Crofton KM, Ding D, Padich R, Taylor M \& Henderson D $2000 a$ Hearing loss following exposure during development to polychlorinated biphenyls: a cochlear site of action. Hearing Research 144 196-204. (doi:10.1016/S0378-5955(00)00062-9)

Crofton KM, Kodavanti PR, Derr-Yellin EC, Casey AC \& Kehn LS $2000 b$ PCBs thyroid hormones and ototoxicity in rats: cross-fostering experiments demonstrate the impact of postnatal lactation exposure. Toxicological Sciences 57 131-140. (doi:10.1093/toxsci/57.1.131)

Crofton KM \& Zoeller TR 2005 Mode of action: neurotoxicity induced by thyroid hormone disruption during development - hearing loss resulting from exposure to PHAHs. Critical Reviews in Toxicology 35 757-769. (doi:10.1080/10408440591007304)

Dauncey MJ, Rudd BT, White DA \& Shakespear RA 1993 Regulation of insulin-like growth factor binding proteins in young growing animals by alteration of energy status. Growth Regulation 3 198-207.

Dündar NO, Dündar B, Cesur G, Yilmaz N, Sütçü R \& Ozgüner F 2010 Ghrelin and adiponectin levels in colostrum cord blood and maternal serum. Pediatrics International 52 622-625. (doi:10.1111/j.1442-200X. 2010.03100.x)

El-bakry AM, El-Ghareeb AW \& Ahmed RG 2010 Comparative study of the effects of experimentally-induced hypothyroidism and hyperthyroidism in some brain regions in albino rats. International Journal of Developmental Neuroscience 28 371-389. (doi:10.1016/j.ijdevneu.2010. 04.003)

Everett CJ, Frithsen I \& Player M 2011 Relationship of polychlorinated biphenyls with type 2 diabetes and hypertension. Journal of Environmental Monitoring 13 241-251. (doi:10.1039/c0em00400f)

http://joe.endocrinology-journals.org DOI: 10.1530/JOE-13-0302
() 2013 Society for Endocrinology Printed in Great Britain
Fain JN \& Bahouth SW 1998 Effect of tri-iodothyronine on leptin release and leptin mRNA accumulation in rat adipose tissue. Biochemical Journal 332 361-366.

Fernandes GS, Arena AC, Fernandez CD, Mercadante A, Barbisan LF \& Kempinas WG 2007 Reproductive effects in male rats exposed to diuron. Reproductive Toxicology 23 106-112. (doi:10.1016/j.reprotox. 2006.09.002)

Fujimoto N, Matsuo N, Sumiyoshi H, Yamaguchi K, Saikawa B, Yoshimatsu H \& Yoshiok H 2005 Adiponectin is expressed in the brown adipose tissue and surrounding immature tissues in mouse embryos. Biochimica et Biophysica Acta 1731 1-12. (doi:10.1016/j.bbaexp.2005.06.013)

Gao XL, Yang HX \& Zhao Y 2008 Variations of tumor necrosis factor- $\alpha$, leptin and adiponectin in mid-trimester of gestational diabetes mellitus. Chinese Medical Journal 121 701-705.

Grimm FA, Lehmler H-J, He X, Robertson LW \& Duffel MW 2013 Sulfated metabolites of polychlorinated biphenyls are high-affinity ligands for the thyroid hormone transport protein transthyretin. Environmental Health Perspectives 121 657-662. (doi:10.1289/ehp.1206198)

Gu JY, Qian CH, Tang W, Wu XH, Xu KF, Scherbaum WA, Schott M \& Liu C 2009 Polychlorinated biphenyls affect thyroid function and induce autoimmunity in Sprague-Dawley rats. Hormone and Metabolic Research 41 471-474. (doi:10.1055/s-0029-1220768)

Hayley S, Mangano E, Crowe G, Li N \& Bowers WJ 2011 An in vivo animal study assessing long-term changes in hypothalamic cytokines following perinatal exposure to a chemical mixture based on Arctic maternal body burden. Environmental Health 10 65. (doi:10.1186/ 1476-069X-10-65)

Houseknecht KL, Mantzoros CS, Kuliawat R, Hadro E, Flier JS \& Kahn BB 1996 Evidence for leptin binding to proteins in serum of rodents and humans: modulation with obesity. Diabetes 45 1638-1643. (doi:10.2337/diab.45.11.1638)

Hytinantti T, Kajantie E, Karonen SL \& Andersson S 2008 Postnatal changes in ghrelin, adiponectin, insulin and leptin concentrations in term newborns. International Journal of Endocrinology and Metabolism $\mathbf{3}$ 127-134.

Jahnke GD, Choksi NY, Moore JA \& Shelby MD 2004 Thyroid toxicants: assessing reproductive health effects. Environmental Health Perspectives 112 363-368. (doi:10.1289/ehp.6637)

Karastergioua K \& Mohamed-Alia V 2010 The autocrine and paracrine roles of adipokines. Molecular and Cellular Endocrinology 318 69-78. (doi:10.1016/j.mce.2009.11.011)

Karcher SC, Small MJ \& VanBriesen JM 2004 Statistical method to evaluate the occurrence of PCB transformations in river sediments with application to Hudson River data. Environmental Science \& Technology $\mathbf{3 8}$ 6760-6766. (doi:10.1021/es0494149)

Kato H, Kashiwagi H, Shiraga M, Tadokoro S, Kamae T, Ujiie H, Honda S, Miyata S, Ijiri Y, Yamamoto J et al. 2006 Adiponectin acts as an endogenous antithrombotic factor. Arteriosclerosis, Thrombosis, and Vascular Biology 26 224-230. (doi:10.1161/01.ATV.0000194076. 84568.81)

Kern PA, Said S, Jackson WG Jr \& Michalek JE 2004 Insulin sensitivity following agent orange exposure in Vietnam veterans with high blood levels of 2,3,7,8-tetrachlorodibenzo-p-dioxin. Journal of Clinical Endocrinology and Metabolism 89 4665-4672. (doi:10.1210/jc. 2004-0250)

Khan MA, Lichtensteiger CA, Faroon O, Mumtaz M, Schaeffer DJ \& Hansen LG 2002 The hypothalamo-pituitary-thyroid (HPT) axis: a target of nonpersistent ortho-substituted PCB congeners. Toxicological Sciences 65 52-61. (doi:10.1093/toxsci/65.1.52)

Kidani T, Kamei S, Miyawaki J, Aizawa J, Sakayama K \& Masuno H 2010 Bisphenol A downregulates Akt signaling and inhibits adiponectin production and secretion in 3T3-L1 adipocytes. Journal of Atherosclerosis and Thrombosis 17 834-843. (doi:10.5551/jat.4051)

Kirkegaard M, Sonne C, Dietz R, Letcher RJ, Jensen AL, Stige HS, Munro JB \& Grandjean P 2011 Alterations in thyroid hormone status in Greenland sledge dogs exposed to whale blubber contaminated with

Published by Bioscientifica Ltd. 
organohalogen compounds. Ecotoxicology and Environmental Safety $\mathbf{7 4}$ 157-163. (doi:10.1016/j.ecoenv.2010.08.040)

Kobayashi K, Miyagawa M, Wang R-S, Suda M, Sekiguchi S \& Honma T 2009 Effects of in utero exposure to $2,2^{\prime}, 4,4^{\prime}, 5,5^{\prime}$-hexachlorobiphenyl on postnatal development and thyroid function in rat offspring. Industrial Health 47 189-197. (doi:10.2486/indhealth.47.189)

Koibuchi N \& Iwasaki T 2006 Regulation of brain development by thyroid hormone and its modulation by environmental chemicals. Endocrine Journal 53 295-303. (doi:10.1507/endocrj.KR-69)

Kokkinos A, Mourouzis I, Kyriaki D, Pantos C, Katsilambros N \& Cokkinos DV 2007 Possible implications of leptin, adiponectin and ghrelin in the regulation of energy homeostasis by thyroid hormone. Endocrine Journal 32 30-32. (doi:10.1007/s12020-007-9002-5)

Koopman-Esseboom C, Morse DC, Weisglas-Kuperus N, Lutkeschipholt IJ, Van der Paauw CG, Tuinstra LG, Brouwer A \& Sauer PJ 1994 Effects of dioxins and polychlorinated biphenyls on thyroid hormone status of pregnant women and their infants. Pediatric Research 36 468-473. (doi:10.1203/00006450-199410000-00009)

Kursunluoglu R, Turgut S, Akin F, Bastemir M, Kaptanoglu B, Genc O \& Turgut G 2009 Insulin-like growth factor-I gene and insulin-like growth factor binding protein-3 polymorphism in patients with thyroid dysfunction. Archives of Medical Research 40 42-47. (doi:10.1016/ j.arcmed.2008.10.009)

Leijs MM, ten Tusscher GW, Olie K, van Teunenbroek T, van Aalderen WM, de Voogt P, Vulsma T, Bartonova A, von Krauss MK, Mosoiu C et al. 2012 Thyroid hormone metabolism and environmental chemical exposure. Environmental Health 11(Suppl 1) S10-S16. (doi:10.1186/ 1476-069X-11-S1-S10)

Lin KT, Xue JY, Sun FF \& Wong PYK 1997 Reactive oxygen species participate in peroxynitrite induced apoptosis in HL 60 cells. Biochemical and Biophysical Research Communications 230 115-119. (doi:10.1006/bbrc.1996.5897)

Maes M, Mommen K, Hendrickx D, Peeters D, D'Hondt P, Ranjan R, De Meyer F \& Scharpe S 1997 Components of biological variation including seasonality in blood concentrations of TSH, $\mathrm{TT}_{3}, \mathrm{FT}_{4}, \mathrm{PRL}$, cortisol and testosterone in healthy volunteers. Clinical Endocrinology 46 587-598. (doi:10.1046/j.1365-2265.1997.1881002.x)

Mandel SJ, Brent GA \& Larsen PR 1993 Levothyroxine therapy in patients with thyroid disease. Annals of Internal Medicine 119 492-502. (doi:10.7326/0003-4819-119-6-199309150)

Marinoni E, Corona G, Ciarda F, Letizia C, Moscarini M \& Di Lorio R 2010 Changes in the interrelationship between leptin, resistin and adiponectin in early neonatal life. Frontiers in Bioscience 2 252-258. (doi:10.2741/65)

Mazaki-Tovi M, Feuermann Y, Segev G, Klement E, Yas-Natan E, Farkas A, Kol A \& Shamay A 2010 Increased serum leptin and insulin concentrations in canine hypothyroidism. Veterinary Journal $\mathbf{1 8 3}$ 109-114. (doi:10.1016/j.tvj1.2008.08.017)

Meerts IA, Assink Y, Cenijn PH, Van Den Berg JH, Weijers BM, Bergman A, Koeman JH \& Brouwer A 2002 Placental transfer of a hydroxylated polychlorinated biphenyl and effects on fetal and maternal thyroid hormone homeostasis in the rat. Toxicological Sciences 68 361-371. (doi:10.1093/toxsci/68.2.361)

Miller MD, Crofton KM, Rice DC \& Zoeller RT 2009 Thyroid-disrupting chemicals: interpreting upstream biomarkers of adverse outcomes. Environmental Health Perspectives 117 1033-1041. (doi:10.1289/ehp. 0800247)

Miller VM, Sanchenz-Morrissey S, Brosch KO \& Seegal RF 2012 Developmental coexposure to polychlorinated biphenyls and polybrominated diphenyl ethers has additive effects on circulating thyroxine levels in rats. Toxicological Sciences 127 76-83. (doi:10.1093/toxsci/kfs089)

Miyazaki W, Iwasaki T, Takeshita A, Tohyama C \& Koibuchi N 2008 Identification of the functional domain of thyroid hormone receptor responsible for polychlorinated biphenyl-mediated suppression of its action in vitro. Environmental Health Perspectives 116 1231-1236. (doi:10.1289/ehp.11176)
Mullerova D, Kopecky J, Matejkova D, Muller L, Rosmus J, Racek J, Sefrna F, Opatrna S, Kuda O \& Matejovic M 2008 Negative association between plasma levels of adiponectin and polychlorinated biphenyl 153 in obese women under non-energy-restrictive regime. International Journal of Obesity 32 1875-1878. (doi:10.1038/ijo.2008.169)

Murk AJ, Rijntjes E, Blaauboer BJ, Clewell R, Crofton KM, Dingemans MM, Furlow JD, Kavlock R, Köhrle J, Opitz R et al. 2013 Mechanism-based testing strategy using in vitro approaches for identification of thyroid hormone disrupting chemicals. Toxicology in Vitro 27 1320-1346. (doi:10.1016/j.tiv.2013.02.012)

Mutaku J, Many M, Colin I, Denef J \& van den Hove M 1998 Antigoitrogenic effect of combined supplementation with $\mathrm{dl}-\alpha$-tocopherol ascorbic acid and $\beta$-carotene and of $\mathrm{dl}-\alpha$-tocopherol alone in the rat. Journal of Endocrinology 156 551-561. (doi:10.1677/joe. $0.1560551)$

Ng PC, Lee CH, Lam CW, Chan IH, Wong E \& Fok TF 2005 Resistin in preterm and term newborns: relation to anthropometry, leptin, and insulin. Pediatrics Research 58 725-730.

Nieminen P, Hyvärinen H, Käkelä R \& Asikainen J 2000 Plasma leptin and thyroxine of mink (Mustela vison) vary with gender diet and subchronic exposure to PCBs. Comparative Biochemistry and Physiology. Part A. Molecular \& Integrative Physiology 127 515-522. (doi:10.1016/ S1095-6433(00)00280-4)

Norstrom K, Czub G, McLachlan MS, Hu D, Thorne PS \& Hornbuckle KC 2010 External exposure and bioaccumulation of PCBs in humans living in a contaminated urban environment. Environment International 36 855-861. (doi:10.1016/j.envint.2009.03.005)

Nunez AA, Kannan K, Giesy JP, Fang J \& Clemens LG 2001 Effects of bisphenol A on energy balance and accumulation in brown adipose tissue in rats. Chemosphere 42 917-922. (doi:10.1016/S00456535(00)00196-X)

Olfert ED, Cross BM \& McWilliam AA (Eds) 1993 In Guide to the care and use of experimental animals, vol 1. Ottawa, Ontario, Canada: CCAC.

Osfor MMH, Elmadbouly MA, Elsoadaa SS, Metair AH \& Hussain AAA 2013 Relation between hypercholesterolemia and insulin like growth factor-1 in elderly women suffer from hypothyroidism. Journal of Natural Sciences Research 3 160-164.

Ozard Y, Tuncer GO, Gunes Y \& Eroz E 2012 Serum levels of leptin, adiponectin and resistin are interrelated and related to total antioxidant capacity free fatty acids and phospholipids in early neonatal life. Clinical Biochemistry 45 298-302. (doi:10.1016/j.clinbiochem. 2011.12.022)

Patrick L 2009 Thyroid disruption: mechanisms and clinical implications in human health. Alternative Medicine Review 14 326-346.

Persky V, Piorkowski J, Turyk M, Freels S, Chatterton R Jr, Dimos J, Bradlow HL, Chary LK, Burse V, Unterman T et al. 2012 Polychlorinated biphenyl exposure diabetes and endogenous hormones: a cross-sectional study in men previously employed at a capacitor manufacturing plant. Environmental Health 11 57-67. (doi:10.1186/ 1476-069X-11-57)

Powers BE, Widholm JJ, Lasky RE \& Schantz SL 2006 Auditory deficits in rats exposed to an environmental PCB mixture during development. Toxicological Sciences 89 415-422. (doi:10.1093/toxsci/kfj051)

Qi Y, Takahashi N, Hileman SM, Patel HR, Berg AH, Pajvani UB, Scherer PE \& Ahima RS 2004 Adiponectin acts in the brain to decrease body weight. Nature Medicine 10 524-529. (doi:10.1038/nm1029)

Ramos S, Goya L, Alvarez C, Martín MA \& Pascual-Leone AM 2001 Effect of thyroxine administration on the IGF/IGF binding protein system in neonatal and adult thyroidectomized rats. Endocrinology 169 111-122. (doi:10.1677/joe.0.1690111)

Ramos S, Goya L, Martin MA, Escriva F \& Pascual-Leone AM 2002 Influence of hypothyroidism on circulating concentrations and liver expression of IGF-binding proteins mRNA from neonatal and adult rats. Endocrinology 172 363-373. (doi:10.1677/joe.0.1720363)

Reutens AT 1995 Evaluation and application of a highly sensitive assay for serum growth hormone $(\mathrm{GH})$ in the study of adult $\mathrm{GH}$ deficiency. 
Journal of Clinical Endocrinology and Metabolism 80 480-485. (doi:10.1210/jc.80.2.480)

Robson H, Siebler T, Shalet SM \& Williams GR 2002 Interactions between GH, IGF-I, glucocorticoids and thyroid hormones during skeletal growth. Pediatric Research 52 137-147. (doi:10.1203/00006450200208000-00003)

Rosenbaum M, Goldsmith R, Bloomfield D, Magnano A, Weimer L, Heymsfield S, Gallagher D, Mayer L, Murphy E \& Leibel RL 2005 Lowdose leptin reverses skeletal muscle autonomic and neuroendocrine adaptations to maintenance of reduced weight. Journal of Clinical Investigation 115 3579-3586. (doi:10.1172/JCI25977)

Saranac L, Stamenkovic H, Stankovic T, Markovic I, Zivanovic S \& Djuric Z 2013 Growth in children with thyroid dysfunction. In Current Topics in Hypothyroidism with Focus on Development pp 119-134. Ed E Potluková. Rijeka, Croatia: Intech Open Access Publisher.

Savino F, Liguori SA \& Lupica MM 2010 Adipokines in breast milk and preterm infants. Early Human Development 86(S1) 77-80. (doi:10.1016/ j.earlhumdev.2010.01.011)

Schantz SL, Widholm JJ \& Rice DC 2003 Effects of PCB exposure on neuropsychological function in children. Environmental Health Perspectives 111 357-376. (doi:10.1289/ehp.5461)

Schell LM, Gallo MV, DeCaprio AP, Hubicki L, Denham M \& Ravenscroft J 2004 Thyroid function in relation to burden of PCBs, p, $\mathrm{p}^{\prime}$-DDE, HCB, mirex and lead among Akwesasne Mohawk youth: a preliminary study. Environmental Toxicology and Pharmacology 18 91-99. (doi:10.1016/ j.etap.2004.01.010)

Scherer PE 2006 Adipose tissue: from lipid storage compartment to endocrine organ. Diabetes 55 1537-1545. (doi:10.2337/db06-0263)

Shagirtha K, Muthumani M \& Miltonprabu S 2011 Melatonin abrogates cadmium induced oxidative stress related neurotoxicity in rats. European Review for Medical and Pharmacological Sciences 15 1039-1050.

Sinjari T \& Darnerud PO 1998 Hydroxylated polychlorinated biphenyls: placental transfer and effects on thyroxine in the fetal mouse. Xenobiotica 28 21-30. (doi:10.1080/004982598239722)

Tang J-M, Li W, Xie Y-C, Guo H-W, Cheng P, Chen H-H, Zheng X-Q, Jiang L, Cui D, Liu Y et al. 2013 Morphological and functional deterioration of the rat thyroid following chronic exposure to low-dose PCB118. Experimental and Toxicologic Pathology. (doi:10.1016/j.etp. 2013.02.001)

Thakur C, Saikia TC \& Yadav RN 1997 Total serum levels of triiodothyronine $\left(\mathrm{T}_{3}\right)$, thyroxine $\left(\mathrm{T}_{4}\right)$ and thyrotropin (TSH) in school going children of Dibrugarh district: an endemic goiter region of Assam. Indian Journal of Physiology and Pharmacology 41 167-170.

Tsai PJ, Yu CH, Hsu SP, Lee YH, Chiou CH, Hsu YW, Ho SC \& Chu CH 2004 Cord plasma concentrations of adiponectin and leptin in healthy term neonates: positive correlation with birth weight and neonatal adiposity. Clinical Endocrinology 61 88-93. (doi:10.1111/j.1365-2265. 2004.02057.x)

Vázquez-Vela ME, Torres N \& Tovar AR 2008 White adipose tissue as endocrine organ and its role in obesity. Archives of Medical Research 39 715-728. (doi:10.1016/j.arcmed.2008.09.005)

Wang Y, Lam KS, Yau MH \& Xu A 2008 Post-translational modifications of adiponectin: mechanisms and functional implications. Biochemical Journal 409 623-633. (doi:10.1042/BJ20071492)

Zare F, Moradizirkohi A, Maghbooli ZH, Hossein-nezhad A, Rahmani M \& Larijani B 2007 Relationship between serum umbilical cord and maternal leptin and adiponectin concentrations with fetal growth parameters. Supplementary issue on osteoporosis. Iranian Journal of Public Health 75-79.

Zimmermann MB 2011 The role of iodine in human growth and development. Seminars in Cell \& Developmental Biology 22 645-652. (doi:10.1016/j.semcdb.2011.07.009)

Zoeller RT, Dowling ALS, Herzig CTA, Iannacone EA, Gauger KJ \& Bansal R 2002 Thyroid hormone brain development and the environment. Environmental Health Perspectives 110(Suppl 3) 355-361. (doi:10.1289/ ehp.02110s3355)

Zoeller RT, Brown TR, Doan LL, Gore AC, Skakkebaek NE, Soto AM, Woodruff TJ \& Vom Saal FS 2012 Endocrine-disrupting chemicals and public health protection: a statement of principles from The Endocrine Society. Journal of Endocrinology 153 4097-4110. (doi:10.1210/en. 2012-1422)

Received in final form 5 September 2013

Accepted 12 September 2013
C 2013 Society for Endocrinology Printed in Great Britain 